\title{
TRADE, TAXATION, AND THE ENVIRONMENT: POSSIBLE IMPACTS OF INDIA - SOLAR CELLS ON BRAZILIAN TAX INCENTIVES FOR THE SOLAR ENERGY SECTOR
}

COMERCIO, TASACIÓN Y MEDIO AMBIENTE: POSIBLES IMPACTOS DE LAS CÉLULAS SOLARES DE LA INDIA SOBRE LOS INCENTIVOS FISCALES BRASILEÑOS PARA EL SECTOR DE ENERGÍA SOLAR

COMÉRCIO, TAXAÇÃO E MEIO AMBIENTE: POSSÍVEIS IMPACTOS DAS CÉLULAS SOLARES DA INNDIA SOBRE OS INCENTIVOS FISCAIS BRASILEIROS PARA O SETOR DE ENERGIA SOLAR

Licença CC BY:

Artigo distribuído sob os termos Creative Commons, permite uso e distribuição irrestrita em qualquer meio desde que o autor credite a fonte original.

\section{Denise Lucena Cavalcante ${ }^{1}$}

Mônica Rocha Victor de Oliveira²

In 2013, the U.S. filed a complaint against India before the World Trade Organization, alleging the inconsistency of certain measures for India relating to domestic requirements under the Jawaharlal Nehru National Solar Mission ("NSM") for solar cells and solar modules with the rules of the GATT, the SCM and the TRIMS (WTO/DS456).

The India - Solar Cells (DS456) case is unique because India's defense under the GATT General Exception Article XX(d) identified international agreements - the preface to the WTO Agreement, the United Nations Framework Convention on Climate Change, the Rio

1 Post-doctor from the University of Lisbon. Ph.D. in Tax Law from PUC/SP. Professor of Tax and Financial Law of the undergraduate and graduate courses - UFC/UNI7. Leader of the Research Group on Environmental Taxation CNPq. Government Attorney at the Ministry of Finances of Brazil.

2 S.J.D. Candidate, Graduate Tax Program, University of Florida, MAS in International Organizations with Specialization in International Economic Organizations. Master in International Law and Economic Integration at the State University of Rio de Janeiro. Member of the American Society of International Law-ASIL and Member of the Society of International Economic Law- SIEL Government Attorney at the Ministry of Finances of Brazil. 


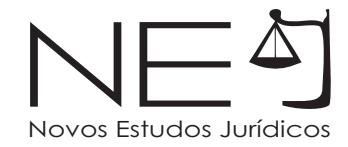

Declaration on Environment and Development (1992), and UN Resolution A/ RES/66/288 (2012) (Rio+20 Document: "The Future We Want") - as "laws and regulations" with which the measures under dispute had to ensure compliance. Nonetheless, both the Panel and the Appellate Body rejected the defense and considered that India failed to demonstrate that the identified international provisions fell within the scope of "laws and regulations."

In this dispute, the obstacles facing the International Environmental system in achieving substantial commitments from the States weakened the defense based on the need for the measures under dispute to secure compliance with domestic "laws and regulations" under GATT, Article XX(d), and jeopardized environmental policies and rules enacted by developing countries, like Brazil, that rely on renewable energy to secure high skilled jobs, transfer of technology and green development policies.

This paper focuses on inconsistencies in the measures with the National Treatment provision of Art. III, 4 of the GATT and the India defense under the General Exception of Art XX(d) of the GATT. The authors are aware of the importance of all the arguments and findings developed during the dispute, and the scope of this paper is restricted by the differences between the legal frameworks of India and Brazil that could have resulted in a different decision by the WTO Dispute Settlement Body.

The first part of the proposed paper will provide a comprehensive analysis of the Reports adopted by the WTO Dispute Settlement Body in the India-Solar Cells dispute, and in particular, the reasons for India's failure to demonstrate that the international environmental provisions were "laws and regulations" for interpreting and applying Article $X X(d)$ of the GATT. The second section is devoted to the identification of Brazilian tax measures enacted to promote the renewable energy sector. The final part demonstrates how the India-Solar Cells decisions could jeopardize the identified tax measures and the development of the renewable energy sector in Brazil.

\section{INDIA - SOLAR CELLS (DS456): THE DISPUTE}

In 2016, the Dispute Settlement Body (DSB) adopted the Appellate Body Report and the Panel Report, as modified by the Appellate Body Report issued in 
the India-Solar Cells dispute (DS456). The measures at stake were part of India's plan for the development of solar energy production adopted by the "Jawaharlal Nehru National Solar Mission" and set the domestic content requirements (DCR) for selling solar energy for the government. The U.S. submission summarized the measures in dispute as follows:

Specifically, it appears India requires solar power developers, or their successors in contract, to purchase and use solar cells and solar modules of domestic origin to participate in the NSM and to enter into and maintain power purchase agreements under the NSM or with National Thermal Power Company Vidyut Vyapar Nigam Limited. As a result, solar power developers, or their successors in contract, receive certain benefits and advantages, including subsidies through guaranteed, long-term tariffs for electricity, contingent on their purchase and use of solar cells and solar modules of domestic origin.

Briefly, the U.S. argued that the measures under dispute were inconsistent with Art. III, 4 of the GATT, Art. 2.1. of the TRIMS, and Art. 3.1(b), 3.2, 5(c), 6.3(a), 6.3(c), 25 of the SCM. India's defense was based on the General Exceptions of Article XX(d) and ( $\mathrm{j}$ ) of the GATT. It argued that the domestic product requirements were enacted to comply with the international environmental agreements and commitments, specifically, the United Nations Framework Convention on Climate Change, the Rio Declaration on Environment and Development (1992), and UN Resolution A/ RES/66/288 (2012) (Rio+20 Document: "The Future We Want").

The Art. XX(d) defense was not accepted by the DSB due to the "soft law" nature of the environmental agreements that India allegedly should secure compliance when requiring domestic content for the granting of the benefits accrued by the "Jawaharlal Nehru National Solar Mission. The ratification of nonbinding international instruments without the enactment of specific domestic legislation was considered insufficient to comply with the standards of the Art. $X X(d)$. The reports also emphasized that the legal instruments cited did not mention the concession of incentives for the solar energy sector.

The Panel considered that international agreements may constitute "laws or regulations" within the meaning of Article XX(d) only insofar as they are rules that have "direct effect" in, or otherwise form part of, the domestic legal system of the Member concerned. The Panel found that most of the instruments identified 
by India did not constitute "laws or regulations" within the meaning of Article $X X(d)$, or were not laws or regulations in respect of which the DCR measures "secure compliance." Thus, the Panel found that India failed to demonstrate that the challenged measures are justified under Article XX(d).

The Appellate Body Report upheld the Panel's finding. The AB report explained that in determining whether a respondent has identified a "rule" that falls within the scope of "laws or regulations" under Article XX(d), it may be relevant for a panel to consider factors such as the degree of normativity of the domestic or international instrument and the extent to which it operates to set out a rule of conduct or course of action that is to be observed within the domestic legal system of a Member.

The DSB adopted the Appellate Body Report and the Panel Report, as modified by the Appellate Body Report, finding that the measures under dispute were inconsistent with Article III, 4 of the GATT and that India failed to justify the discriminatory treatment under the General Exceptions of the Article $X X(d)$ and (j) of the GATT.

Brazil reserved its third party rights, including the similar stage of the solar energy production in both countries and the granting of incentives for the sector. However, the Brazilian energy and environmental legal framework, and the tools for implementing the public policies intended to develop the solar energy sector, are significantly different as described in the next section.

\section{INTERNATIONAL AND DOMESTIC ENVIRONMENT, CLIMATE CHANGE AND RENEWABLE ENERGY LEGAL FRAMEWORK IN BRAZIL}

In Brazil, the concern with environmental preservation and conservation is high and explains Brazil's active role in international environmental negotiations and, domestically, the approval of laws and regulations related to the environment, climate change and renewable energy in a complex and intertwined set of policies and actions. 


\subsection{INTERNATIONAL FRAMEWORK}

Brazil played an active role in the International Environmental Agreement negotiations and held the first multilateral environmental conference in 1992, ECO-RIO, when the Rio Declaration was signed and the directives drawn up for the negotiation of further agreements and commitments. Brazil has signed and ratified all the relevant international instruments, such as United Nations Framework Convention on Climate Change, the Rio Declaration on Environment and Development (1992), and UN Resolution A/RES/66/288 (2012) (Rio+20 Document: "The Future We Want"), all of them cited in India's defense.

\section{2. DOMESTIC CLIMATE CHANGE AND ENVIRONMENT LEGAL}

FRAMEWORK

In 2009, Law 12.187/09 establishing the National Policy on Climate Change was approved. The National Policy for Climate Change Law defines the principles, objectives, directives, and tools for public policies for mitigating the effects of climate change. Among the principles for the National Policy for Climate Change, the precautionary principle, sustainable development, and common but differentiated responsibilities at the international level, were recognized domestically. Furthermore, Article 6, VI of the aforementioned law determined that tax measures are tools for reaching the goals established by the National Policy for Climate Change. i.e., tax exemptions and incentives enacted by specific law.

\subsection{DOMESTIC ENERGY LEGAL FRAMEWORK}

In 1997, the Congress enacted the National Energy Policy Law that established the goals for efficient development and use of the energy from different sources. Among the 18 identified goals, we highlight the protection of environment and promotion of energy conservation, the use of alternative energy sources, research and development incentives for the renewable energy sector, and the mitigation of greenhouse gas emissions and other pollutants related to the energy and transportation sectors ${ }^{3}$.

3 Lei 9.478/1997, Article 1, IV, VIII, XVII and XVIII. 
In 2002, the Program of Incentives for Electric Energy (PROINFA - "Programa de Incentivo às Fontes de Energia Elétrica") was established to give financial incentives to the production of renewable energy and enhance the competitiveness of the sector, particularly wind energy and biomass plants. Following that, the Congress approved Law 11,097/2005, including the incentives for the renewable energy national program, the production and use of solar energy and other alternative sources of energy.

The production of solar energy in Brazil is in its early stages, and the regions with higher production and distribution potential are in social and economically disadvantageous areas in Brazil. Thus, the development of the solar energy sector, through preferential tax regimes, is crucial for the implementation of public policies related not only to environmental preservation and conservation and renewable energy promotion, but also to economic development and poverty reduction.

\section{THE INCENTIVES FOR THE SOLAR ENERGY SECTOR IN BRAZIL}

In Brazil, low-interest rate loans provided by federal and regional foment agencies, and federal and local tax exemptions or tax rates reductions are the usual fiscal and taxation tools used to implement environmental and energy national public policies.

The "Banco Nacional de Desenvolvimento Econômico e Social" (BNDES), a federal foment agency, provides for long-term and low-interest rates loans and is the most important source of incentives for the solar energy sector. The concession of loans is subject to domestic content rules, and the higher ratio of national content used in the production of the solar energy corresponds to lower interest rates and longer terms. The system is inspired by the successful experience of a similar program for wind energy, despite the profound differences between both sectors, i.e., size and complexity difference between the tools used to produce wind energy and solar energy. Not to mention the reduction of incentives for the wind energy sector in Europe, particularly Germany, that shifted the patterns of foreign investments of the wind energy sector. 
The eligibility for the BNDES preferential loans is conditioned to the progressive nationalization of components and process during the project implementation period, and the solar energy producer must prove the progressive nationalization of components and processes in different stages of the project. Now, the minimum national content ratio is $50 \%$ to be achieved by $09 / 30 / 2018$.

Brazil opted for a different domestic requirement content (DCR) compared to India, allowing the eligibility of projects using imported equipment, and requiring the progressive use of domestic components. Brazil chose the progressive nationalization system, while India opted for the progressive denationalization system. The reason behind the Brazilian choice was the costs and delays for solar energy production that would derive from domestic content requirements, whereas Brazil did not have domestic solar energy components enough to supply the national demand, and IP rights related to solar energy production. Of course, that choice was followed by complaints from the solar components manufacturers in opposition to the solar energy suppliers that targeted lowering production costs and increasing the sector competitiveness.

In fact, the national production of solar energy components in Brazil suffers from the lower prices of imported goods, mainly from China, where the manufacturing costs are lower, and government subsidies are higher.

\section{TAX INCENTIVES AND DOMESTIC CONTENT REQUIREMENTS}

Tax incentives to produce solar energy conditioned to domestic content were granted both by the federal and local governments, and preferential tax regimes were approved for the sector, whether for disadvantageous economic areas or for early stage industries. Bills proposing a variety of tax incentives for the renewable energy sector are under discussion in the National Congress, and soon, more tax incentives will be granted to the sector with the reduction of tax rates and approval of exemptions federal taxes, i.e., social contributions.

The solar energy components production related to the IT sector benefits from the federal taxes exemption provisions of Law 8,248/91 - "Lei da Informática" 
(IT Law). Among other benefits, domestic IT goods and services are exempt from or subject to a lower rate regarding income tax, manufactured products tax, and social contributions. The Brazilian IT preferential Tax Regime was recently considered inconsistent with the WTO Agreements by the Panel report on BrazilTaxation (DS472).

The report is the most comprehensive Trade Related to Taxation (TRT) decision issued by the DSB to date, because the measures under dispute are related to both direct and indirect taxes, preferential tax regimes for disadvantaged economic areas, conditioned to Domestic Content Requirements (DCR), environmental tax incentives, tax incentives for the protection of public morals, and tax incentives for the protection of human, animal and plant life and health, according to Brazil's defense.

The WTO adopted reports does not have retroactive effects; thus no retroactive compensation could be pursued under the WTO system. However, the adoption of the report will trigger different results in the Brazilian domestic legal system due to the peculiarities of the Brazilian process of incorporation of international agreements, and the conflict of norm provisions, in particular, Article 98 of the Tax Code.

International binding agreements, once approved by the National Congress and ratified by the President, are considered part of the domestic law. Moreover, after they have been ratified and are internationally in force, international agreements have direct application. Consequently, the WTO agreements are part of the Brazilian domestic legal system at the same hierarchy level as domestic laws.

The Brazilian National Tax Code has a specific provision about international agreements not only applicable to Tax Treaties but to any other agreement, treaty, convention or binding instrument applicable to taxes, tariffs and any different kind of charges - Article 98 of the National Tax Code:" treaties and international conventions revoke or modify the internal tax laws, and will be observed by the ones which befall them later". Article 98 not only provides that any international binding agreement should be considered at the same hierarchy level as domestic statutes, but also prohibits international treaties to be overridden. Therefore, considering that the WTO agreements are part of the Brazilian domestic legal 
system, the tax measures under dispute are also inconsistent with Brazil's domestic law - WTO agreements regularly approved and ratified, and under Article 98 of the Brazilian Tax Code, WTO agreements prevail over any subsequent tax law. Consequently, the tax authority should carry out the tax credit assessment and collect unpaid taxes.

The "Convênio ICMS 6/2013" recommended the enactment of local tax laws granting tax incentives for the solar sector when sales taxes are imposed. Recently, the Ceará Legislative Assembly approved the PROCEDES ("Programa Cearense de Desenvolvimento Sustentável"), a local program for the sustainable development of the region. According to the PROCEDES' provisions, solar energy components $100 \%$ produced in Ceará are exempt from ICMS and subject to a $50 \%$ rate when produced in other states.

The production of solar energy in Brazil is in its early stages, and the regions with higher potential to produce solar energy are located in social and economically disadvantaged areas. Thus, the development if the sector, through preferential tax regimes, is crucial not only for public policies related to environmental preservation and conservation, and renewable energy sector development, but also to economic development and poverty reduction.

\section{FINAL CONSIDERATIONS}

According to the data available on the National Energy Progress Report published by the Ministry of Mining and Energy of Brazil, the incentivized micro and mini solar energy distribution and compensation system (net metering) reached 104.1 GWh per 72.5 MW of energy plants. Undoubtedly, the public policies implemented in Brazil triggered a broader participation of the solar energy sector in the total energy production, yet this participation is insignificant when compared with the solar energy production potential and the excellent weather conditions in Brazil. The development of the solar energy sector in Brazil is still incipient, and demands the implementation of public policies for the sector.

Ensuring consistency of the measures for the development of the solar energy sector in Brazil with international commitments and rules is challenging, and the 
fluidity of the International Environmental system does not provide a safe harbor for development focused policies for the sector. The different options taken by Brazil and India regarding the domestic content requirements demonstrated the absence of international guidelines to assist the development of renewable energy production. Therefore, developing countries are struggling to implement laws and regulations that are consistent with other international legal systems, e.g., international trade. Moreover, the principle of common but different responsibilities, the focal point of the International Environmental system, was not considered by both countries when enacting laws and regulations for the development of the solar energy sector.

The balance among development, trade liberalization, environment, and taxation is extremely complex due to different degrees of normalization among the systems, weak institutional links among the various international bodies responsible for the different areas.

Although enormous efforts had been made in the last couple of years to enhance cooperation among International Organizations, the institutional links are yet to be consolidated. The scenario weakens the developing countries technical capacity to deal with sensitive and complex matters.

Although India and Brazil's DCR legislation was considered inconsistent with the WTO agreements, a new dispute between India and the U.S. concerning the environmental tax incentives for the renewable energy sector will be decided in the U.S. - Renewable Energy (DS510). That set of decisions will determine the design and implementation of energy policies in all Member States. Hopefully, the World Trade Organization decisions will enlighten both developed and developing countries and recognize the importance of the development of the renewable energy sector for the welfare of future generations.

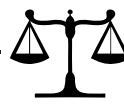

Recebido em: abril/2018

Aprovado em: julho/2018 